\title{
Maternal Tobacco Smoking and Lung Epithelium-Specific Proteins in Amniotic Fluid
}

\author{
CEDRIC HERMANS, VALÉRIE LIBOTTE, MARJORIE ROBIN, ANDRÉ CLIPPE, \\ RUDDY WATTIEZ, PAUL FALMAGNE, JEAN PAUL LANGHENDRIES, ALFRED BERNARD \\ Industrial Toxicology and Occupational Medicine Unit, Faculty of Medicine, Catholic University of \\ Louvain, Brussels, Belgium [C.H., V.L., M.R., A.C., A.B.]; Department of Biological Chemistry, University \\ of Mons-Hainaut, Mons, Belgium [R.W., P.F.]; Neonatology Intensive Care Unit, Saint-Vincent Clinics, \\ Rocourt, Belgium [J.P.L.]
}

\begin{abstract}
The bronchiolar $16 \mathrm{kD}$ Clara cell secretory protein (CC16) and the alveolar surfactant-associated protein A (SP-A) are secreted in the amniotic fluid (AF), where they reflect the growth and the maturity of the fetal lung. To evaluate the possible effects of in utero tobacco smoke exposure upon infant bronchoalveolar epithelium function and maturity, CC16 and SP-A levels were determined in $\mathrm{AF}$ obtained at term $(36-41 \mathrm{wk})$ from 28 nonsmoking, 18 smoke-exposed, and 28 smoking mothers with uncomplicated pregnancies. Tobacco smoke exposure was assessed by questionnaire and the assay in AF and maternal urine of cotinine, a stable nicotine metabolite. The specificity of the changes of CC16 and SP-A concentrations in AF was assessed by comparison with nonpulmonary proteins of high- (albumin and transferrin) or low-molecular weight ( $\beta_{2}$-microglobulin, retinol binding protein, cystatin-C). Pulmonary and nonpulmonary $\mathrm{AF}$ proteins were also compared by two-dimensional gel electrophoresis between smoking and nonsmoking mothers. The levels of CC16 and SP-A as well as low- and high-molecularweight proteins were not significantly different between the three smoking categories. The protein pattern of AF, established by two-dimensional gel electrophoresis, did not reveal any quantitative or qualitative difference between nonsmoking $(n=10)$, smoke-exposed $(n=5)$, and smoking mothers $(n=5)$. By multiple regression analysis of possible determinants, tobacco
\end{abstract}

\section{ABSTRACT}

smoke did not emerge as a significant predictor of CC16 and SP-A concentrations in AF. SP-A level was dependent only on gestational age at birth $\left(r^{2}=0.1, p=0.001\right)$, whereas CC16 correlated only with the levels of low-molecular weight proteins $\left(r^{2}=0.2, p=0.0001\right)$. The latter correlation suggests that $\mathrm{CC} 16$ enters AF not only as a result of its secretion at the surface of the respiratory tract but also partly following its elimination by the fetal kidney. This study suggests that maternal smoking during pregnancy is not associated with alterations of the secretory functions of the epithelium of the distal airways and the alveoli at term. (Pediatr Res 50: 487-494, 2001)
Abbreviations
2-DE, two-dimensional electrophoresis
AF, amniotic fluid
$\boldsymbol{\beta}_{\mathbf{2}}-\mathbf{m}, \beta_{2}$-microglobulin
CC16, 16-kD Clara cell secretory protein
HMWP, high-molecular-weight proteins
IOD, integrated OD
LIA, latex immunoassay
LMWP, low-molecular-weight proteins
PVDF, polyvinylidene difluoride
RBP, retinol binding protein
SP-A, surfactant-associated protein A

Maternal smoking during pregnancy is associated with an increased incidence of respiratory illnesses for children during infancy and later in childhood (1-3). Impaired airway function has also been described in both term and preterm infants of smoking mothers, suggesting that maternal smoking probably alters airway and alveolar growth during fetal life (4-7). No

Received July 19, 2000; accepted May 31, 2001.

Correspondence and Reprint Requests: Cedric Hermans, M.D., M.R.C.P. (U.K.), Ph.D., Unit of Industrial Toxicology and Occupational Medicine, Faculty of Medicine, Catholic University of Louvain, 30.54 Clos Chapelle-aux-Champs, B-1200 Brussels, Belgium; e-mail: hermans@toxi.ucl.ac.be

Supported by the European Union (EV4-CT96-0171) and the Office of the Scientific, Technical and Cultural Affairs of the Belgian Government. causal mechanisms for these clinical and functional effects have so far been clearly delineated.

The pulmonary epithelium is a major target of injury by tobacco smoke toxicants in adults. Some of these toxicants with lipophilic properties are transferred from the mother to the fetus through the placenta $(8,9)$ and are likely bioactivated in more toxic compounds by fetal pulmonary epithelial cells (10). One may therefore hypothesize that maternal smoking might alter in utero the development and secretory functions of epithelial cells lining the fetal airways and alveoli.

Recently, the measurement of lung epithelium proteins in AF has been proposed as an original and innovative approach to evaluate adverse effects of lung toxicants on the pulmonary 
epithelium. Among these proteins are $\mathrm{CC} 16$, the main secretory product of bronchiolar nonciliated Clara cells, and SP-A, the major surfactant apoprotein, secreted by both alveolar type II and Clara cells (11). CC16 and SP-A appear in AF from about 15 and $26 \mathrm{wk}$, respectively, and progressively increase during pregnancy, reflecting the development of the airways and the alveoli (12-15). This time course and the decreased levels of CC16 and SP-A in AF from fetuses with diaphragmatic hernia and diabetic pregnancy, two situations leading to lung hypoplasia or immaturity, suggest that these proteins in AF might be good indices of the development of fetal airways and alveoli $(12,16,17)$. Clara cells are also known to be very sensitive to a number of air pollutants, including tobacco smoke $(18,19)$. Finally, both proteins have important properties by which they protect the respiratory tract from aggressions $(20,21)$.

In this study, we have examined the influence of maternal smoking on the fetal pulmonary epithelium maturity and secretory functions by measuring the $\mathrm{CC} 16$ and SP-A in AF and establishing the two-dimensional protein map of AF obtained at delivery.

\section{METHODS}

\section{Study Population}

This study was approved by the Research Ethics Committee of the Cliniques Universitaires Saint-Luc, Brussels (Permit 97/151). The study population included 153 consecutive women who attended the birth clinic of the Cliniques St.Vincent, Rocourt, between March and July 1998. All participants provided informed written consent and had singleton births and no evidence of complications or treatment during pregnancy known to be associated with alterations of fetal lung maturation. Among this population, 74 women fulfilled the following criteria and were selected for the study. The gestational age at time of delivery, determined from the woman's last menstrual period, was between 36 and $41 \mathrm{wk}$. A sample of amniotic fluid of sufficient volume (at least $5 \mathrm{~mL}$ ) and not visibly contaminated by blood was collected vaginally following artificial or spontaneous rupture of membranes. In addition, women provided a sample of blood and urine collected within $2 \mathrm{~h}$ of delivery. Amniotic fluid and blood were centrifuged at $3000 \times g$ for $10 \mathrm{~min}$. The supernatants of the $\mathrm{AF}$ as well as serum and urine samples were stored at $-80^{\circ} \mathrm{C}$ until analysis. Information regarding exposure to active and passive tobacco smoking and other sources of airborne pollutants during pregnancy (heating and cooking systems; location of residence within urban, suburban, or rural areas; driving habits and type of cars; proximity to busy roads; characteristics of home and occupation) was obtained by questionnaire completed by the mother after delivery at the birth clinic. Participants had no evidence of occupational exposure to lung toxicants during pregnancy.

Fetal smoke exposure was assessed by the measurement of cotinine in maternal urine and $\operatorname{AF}(22,23)$. Cotinine is routinely used as a measure of smoke exposure because its halflife is longer than that of nicotine and it is present at higher concentrations than the parent compound (22). Mothers were classified as nonsmokers during their pregnancy if they reported that they had never smoked and their cotinine level was below the detection limit in both urine and AF. Women were classified as smokers if they reported smoking (more than five cigarettes per day) during their pregnancy, irrespectively of the cotinine levels in AF and urine. Women who did not report to have smoked but had detectable cotinine levels in urine and AF at time of delivery were classified as smoke exposed.

Concentrations of CC16 and SP-A in AF were used as indices of epithelium lung maturation and/or integrity. The specificity and the determinants of the changes of these lung epithelium proteins were studied by comparison with nonpulmonary LMWP present in AF: RBP, a $21-\mathrm{kD}$ liver protein; $\beta_{2}-\mathrm{m}$, a $11.8-\mathrm{kD}$ ubiquitous protein; and cystatin-C, a cysteine protease inhibitor produced by most nucleated cells (24-26). Levels of CC16 and SP-A in AF were also compared with those of albumin and transferrin, two HMWP originating from the fetal liver. By contrast with CC16 and SP-A, which are secreted at the surface of the epithelium lining the airways and the alveoli, these nonpulmonary LMWP and HMWP are components of the fetal urine, and their levels in AF reflect the maturity of the fetal kidney (27-30). Because glucocorticoids play an important role in the pulmonary development and are considered to mediate the well-known acceleration of the fetal lung maturation in smoke-exposed mothers, the level of free cortisol was determined in AF and its relationship with the other parameters in AF studied (31).

\section{CC16 Assay}

The concentration of $\mathrm{CC} 16$ was determined by a sensitive immunoassay relying on the agglutination of latex particles, as previously described (32). The validity and the analytical performances of the CC16 LIA in different biologic media have been reported previously $(12,33)$. Briefly, applied to serum, this assay has a detection limit of $0.5 \mu \mathrm{g} / \mathrm{L}$ and an average analytical recovery of $95 \%$. The within- and betweenrun coefficients of variation range from 5 to $10 \%$. Because AF must be diluted at least 40 times to get a linear response, the lowest concentration measurable with precision in this fluid was $15 \mu \mathrm{g} / \mathrm{L}$ (12).

\section{SP-A Assay}

For the measurement of SP-A, we used an inhibition enzyme immunosorbent assay comparable to that developed by Doyle and colleagues (34). That assay uses commercial antibodies directed against SP-A, isolated from bronchoalveolar lavage fluid of patients with alveolar proteinosis and purified by the method of Haagsman and co-workers (Chemicon International Inc., Temecula, CA, U.S.A.). These antibodies react strongly with normal and proteinosis glycosylated and unglycosylated SP-A, as well as with the nonthiol-dependent dimers and oligomers of SP-A, but they do not cross-react with other human components of human lavage, amniotic fluid, or serum. Purified human SP-A, kindly provided by J.R. Wright (Department of Cell Biology, Duke University Medical Center, Durham, NC, U.S.A.), was used as standard. Analytical recov- 
ery of the assay was $89.6 \%$. The within- and between-run coefficients of variation were $7.7 \%$ and $13.7 \%$, respectively.

\section{Other Assays}

Creatinine in $\mathrm{AF}$ and maternal serum was determined by the Jaffé's method. Total protein in AF was determined by the Coomassie blue method (Bayer Diagnostics, Brussels, Belgium). $\beta_{2}-\mathrm{m}, \mathrm{RBP}$, cystatin-C, albumin, and transferrin in $\mathrm{AF}$ were measured by LIA as previously described $(35,36)$. The levels of cortisol (in AF) and cotinine (in AF and maternal urine) were determined for all patients. The techniques used to measure these parameters have been detailed elsewhere (37, 38).

\section{2-DE}

Sample preparation. 2-DE was performed on samples of amniotic fluids collected from smoking mothers $(n=5)$, smoke-exposed mothers $(n=5)$, and nonsmoking mothers $(n=5)$. Cumulative smoking (arithmetic mean $\pm \mathrm{SD}$, in pack-months) of the selected smoking mothers was $5.3 \pm 2.3$. For each sample, the protein concentration was measured by using the bicinchoninic acid protein assay according to the instructions of the manufacturer. The samples were then diluted in sample solution, mixed by sonication, and finally centrifuged at $30,000 \times g$ for $30 \mathrm{~min}$ to remove any undissolved material. The supernatant was used for 2-DE analysis, as previously described (39)

2-DE. 2-DE was performed in a horizontal Multiphor 2-DE set-up (Pharmacia, Uppsala, Sweden) according to the procedure described by Görg (40). Immobilized $\mathrm{pH}$ gradients strips $(0.5 \times 3 \times 180 \mathrm{~mm})$, containing Immobilines NL 3-10, were rehydrated overnight in rehydration solution. The firstdimension separation was then performed by applying $40 \mu \mathrm{g}$ protein/sample in volume of $150 \mu \mathrm{L}$ at the anodic side. The gels were run on a Pharmacia Multiphor II system equipped with a Multidrive XL power supply (Pharmacia Biotech, Uppsala, Sweden) using a three-phase program. Second-dimension separations (SDS-PAGE) were carried out with Excelgel XL SDS 12-14 (Pharmacia) $(0.5 \times 180 \times 245 \mathrm{~mm})$. Staining with silver nitrate of the 2-DE gels was performed, as described by Rabilloud et al. (41). Protein pI and $M_{\mathrm{r}}$ were respectively assigned by calibration of 2D-PAGE gels with carbamylyte $\mathrm{pI}$ calibration markers and molecular weight standard proteins (Pharmacia Biotech).

Evaluation of 2-D pattern. The protein patterns in the gels were analyzed as digitalized images using a high-resolution scanner ( 8 bits/pixel) in combination with PDQuest software (Bio-Rad, Richmond, CA, U.S.A.). The amount of protein in a spot was assessed as background-corrected OD, integrated over all pixels in the spot and expressed as IOD. To correct for differences in total staining intensity between different 2-DE images, the amounts of different spots were expressed as the percentage of the individual spot IOD per total IOD of all the spots (\% IOD) (42).

Electroblotting. Proteins were electroblotted onto PVDF membranes (Sequi-Blot PVDF membrane; Bio-Rad). The
PVDF membrane-bound proteins were visualized by staining with Coomassie Brilliant Blue R-250.

$N$-terminal amino acid microsequence analysis. Spots on the PVDF membrane were excised and the protein N-terminal amino acid sequences were currently determined at the picomol level by automated Edman degradation. For internal sequencing, samples were digested in the presence of trypsin, and peptides were purified by capillary reverse phase HPLC (39, 43).

Computer search for protein identity or similarity. Amino acid sequence comparisons were carried out using the FASTA or the TFASTA computer program of the Genetics Computer Group for screening protein or nucleic acid databases. The international databases were SWISS-PROT (release 34), PIR (release 50), Genpept, Genpeptnew, GenEMBL (release 53), Genbank (release 105), GenEMBLnew (release 53+), and IMGT (release 97.06).

\section{Statistical Analysis}

The variables were not normally distributed and were logtransformed before the application of parametric tests. Results are expressed as geometric mean and range. In the initial analysis, the groups, classified according to exposure to tobacco smoke, were compared with respect to mothers' and newborns' characteristics as well as biochemical parameters in AF by one-way ANOVA followed by the Dunett's multiple comparison test. The associations between parameters in AF were tested using the Spearman rank order correlation test. Potential determinants affecting the levels of $\mathrm{CC} 16$ and SP-A in $\mathrm{AF}$ were then identified in different models of stepwise regression analysis. A first predictor tested was tobacco smoke exposure in utero. We also tested the influence of other sources of outdoor or indoor air pollutants identified in the study. Besides these variables, the levels of CC16 and SP-A in AF may be determined by the maturity of the respiratory tract, which increases with gestational age. In adults, CC16 is known to leak from the lung into the blood and to be freely eliminated by the kidney. By contrast, all evidence available so far points to an extrarenal, although not yet identified, route for the clearance of SP-A present in the systemic circulation. Therefore, concentrations in AF of CC16, but unlikely of SP-A, may, in part, be influenced by the degree of maturity of the fetal kidney as estimated by LMWP and HMWP in AF. Finally, CC16 and SP-A levels may be affected by differences between smokers and nonsmokers in the amount of AF (which decreases with advancing pregnancy) and its turnover near birth, of which creatinine concentration in $\mathrm{AF}$ was used as a surrogate. Therefore, we hypothesized that independent variables influencing $\mathrm{CC} 16$ and SP-A might include exposure to tobacco smoke [categorized as nonsmoker (0), smoke-exposed (I), and active smoker (II)], exposure to other sources of outdoor or indoor air pollutants [categorized as absent (0) or present (1)], gestational age at birth (in weeks), LMWP (as estimated by RBP, $\beta_{2}-\mathrm{m}$, or cystatin-C levels in AF), HMWP (as estimated by albumin or transferrin levels in $\mathrm{AF}$ ), and $\mathrm{AF}$ creatinine levels. The level of statistical significance was set at $p<0.05$. 


\section{RESULTS}

The characteristics of the study population are given in Table 1. Women were considered as nonsmokers in 28 cases, tobacco smoke exposed in 18 cases, and voluntary smokers in 28 cases. For smoking mothers, the cumulative smoking during pregnancy was $5.5(2.2-18)$ pack-months. The average interval between last cigarette consumption and delivery was 7.7 (1$200) \mathrm{h}$. The daily average tobacco consumption before delivery was approximately $2(1-20)$ cigarettes per day, which is significantly lower than that of $10.2(1-40)$ cigarettes per day reported during pregnancy. The three categories were, on the whole, well matched with respect to newborns' sex, gestational and maternal age, and renal function estimated on the basis of creatinine in serum. Body weight of newborns of smoking mothers was on average $300 \mathrm{~g}$ lower than those of nonsmoking and smoke-exposed mothers and negatively correlated with the cumulative smoking during pregnancy $(n=28, r=0.43$, slope: $-0.126, p=0.01)$.

With respect to exposure to outdoor pollutants, 35 (47\%) mothers lived in rural areas remote from any source of pollution. Thirty-nine mothers (53\%) were from urban or peri-urban areas or reported presence of major industry or main road in the vicinity of their residence. Use of a gas cooker was the only source of indoor pollution identified for 31 mothers (41\%). Exposure to indoor or outdoor pollutants did not differ between the three smoking categories. None of the participants had evidence of occupational exposure to lung toxicants during pregnancy. Only six mothers involved in health care were suspended from work during their pregnancy because of infectious hazards.

Table 2 shows the levels of biochemical parameters in $\mathrm{AF}$ for the whole population and for each category of smoke exposure considered separately. CC16 and SP-A as well as the SP-A/CC16 ratio did not differ between smokers, smoke exposed, and nonsmokers. No significant difference was also found when mothers were classified according to the level of cotinine in AF or in urine (data not shown). LMWP and HMWP showed the same pattern of concentrations in AF from the three smoking categories. The AF cortisol content was not different in the three categories.

Figure 1 shows typical electrophoretograms of AF proteins obtained at term from a nonsmoking and a smoking mother. The total number of spots on the 20 samples of AF tested within the window of pI 3.5-9.5 and molecular mass 5-100 kD was on average 850 and did not differ significantly between smoking categories. Thirteen proteins were identified either by $\mathrm{N}$-terminal microsequencing $(n=9)$ or by matching with the 2-D electrophoretic protein map at $17 \mathrm{wk}$ gestation previously reported by Liberatori and colleagues $(n=4)$. The amounts of lung epithelium-specific proteins on the protein map (geometric mean and range, expressed as \% IOD) was $0.032(0.01-$ $0.11)$ for CC16 and $0.009(0.006-0.013)$ for SP-A, and was not significantly different for the three smoking categories (data not shown). The electrophoretic pattern of nonpulmonary proteins identified in AF (albumin, transferrin, RBP, and $\beta_{2}-\mathrm{m}$ ) showed no differences between smokers and nonsmokers.

As shown in Table 3, CC16 concentration in amniotic fluid was correlated with that of all LMWP and HMWP measured in $\mathrm{AF}$, the strongest correlations being found with LMWP. By contrast, SP-A level in AF was not related to any other protein but positively correlated with gestational age at birth (Fig. 2). Significant correlations were found between the four LMWP and the two LMWP measured in AF. The latter also correlated with the total protein content of AF. The concentration of creatinine in $\mathrm{AF}$ was found to be independent of all parameters tested.

Among the variables tested by stepwise regression analysis (smoke exposure, exposure to outdoor and indoor air pollutants, gestational age at birth, LMWP and HMWP in AF, creatinine level in AF), only nonpulmonary LMWP or HMWP were significantly associated with the content of CC16 in AF. Of interest, nonpulmonary LMWP in AF accounted for 14 to $25 \%$ of the variance of $\mathrm{CC} 16$ in $\mathrm{AF}$, which suggests that, on average, $20 \%$ of $\mathrm{CC} 16$ enters $\mathrm{AF}$ by renal excretion. Using similar regression models, SP-A levels in AF was influenced only by the duration of gestation. Smoke exposure in utero as

Table 1. Characteristics of the population

\begin{tabular}{|c|c|c|c|c|c|}
\hline & $\begin{array}{l}\text { Whole population } \\
\qquad n=74\end{array}$ & $\begin{array}{c}\text { Nonsmokers } \\
n=28\end{array}$ & $\begin{array}{c}\text { Smoke-exposed } \\
n=18\end{array}$ & $\begin{array}{c}\text { Active smokers } \\
n=28\end{array}$ & $p$-Value* \\
\hline \multicolumn{6}{|l|}{ Mothers } \\
\hline Age, yr & $29.1(18-42)$ & $29.6(20-42)$ & $28.7(18-33)$ & $28.8(22-39)$ & 0.74 \\
\hline Serum creatinine $(\mathrm{mg} / \mathrm{L})$ & $7.5(3.7-13.4)$ & $7.7(5.8-12.4)$ & $7.1(3.7-10.2)$ & $7.5(4.8-13.4)$ & 0.4 \\
\hline Serum CC16 $(\mu \mathrm{g} / \mathrm{L})$ & $7.4(2.6-17.6)$ & $7.5(2.6-17.6)$ & $7.8(3.4-15.3)$ & $7.0(3.2-12.6)$ & 0.63 \\
\hline Cumulative smoking (pack-months) & - & - & - & $5.51(2.2-18.0)$ & \\
\hline Urinary cotinine/creatinine $(\mu \mathrm{g} / \mathrm{g})$ & - & $2.04(0.76-5.95)$ & $4.98 \dagger(1.37-46.6)$ & $38.23 \dagger, \S(1.38-650.0)$ & 0.0001 \\
\hline Amniotic cotinine $(\mu \mathrm{g} / \mathrm{L})$ & - & ND & $10.6 \dagger(6.0-23.0)$ & $46.3 \dagger, \S(7.0-300.0)$ & 0.0001 \\
\hline \multicolumn{6}{|l|}{ Newborns } \\
\hline Gestational age at birth, mo & $39.2(36-41)$ & $39.1(37-41)$ & $39.7(38-41)$ & $39.1(36-41)$ & 0.21 \\
\hline $\operatorname{Sex}(M / F)$ & $37 / 37$ & $14 / 14$ & $11 / 7$ & $12 / 16$ & NS \\
\hline Body wt, g & $3216(2235-4100)$ & $3300(2235-4100)$ & $3377(2980-4050)$ & $3036 \dagger, \S(2340-4000)$ & 0.0074 \\
\hline Height, cm & $49.5(39-53)$ & $49.6(39-53)$ & $49.8(48-51)$ & $49.2(45-52)$ & 0.61 \\
\hline
\end{tabular}

Values are given as geometric mean with range.

* Differences between smoking categories were assessed by ANOVA followed by Dunnett's multiple comparison test.

$\uparrow$ Significantly different from nonsmokers $(p<0.05)$.

$\S$ Significantly different from smoke-exposed $(p<0.05)$. 
Table 2. Parameters in amniotic fluid according to smoking habits

\begin{tabular}{|c|c|c|c|c|c|}
\hline & $\begin{array}{l}\text { Whole population } \\
\qquad n=74\end{array}$ & $\begin{array}{c}\text { Nonsmokers } \\
n=28\end{array}$ & $\begin{array}{c}\text { Smoke-exposed } \\
n=18\end{array}$ & $\begin{array}{c}\text { Active smokers } \\
\quad n=28\end{array}$ & $p$-Value* \\
\hline $\mathrm{CC} 16(\mu \mathrm{g} / \mathrm{L})$ & $246(66-1311)$ & $234(66-916)$ & 247 (77-1109) & $257(114-1311)$ & 0.86 \\
\hline SP-A $(\mu \mathrm{g} / \mathrm{L})$ & $4855(225-89,692)$ & $4518(225-15,261)$ & $5896(1017-89,692)$ & $4604(469-50,748)$ & 0.66 \\
\hline $\mathrm{SP}-\mathrm{A} / \mathrm{CC} 16$ ratio & $17.7(0.9-272.6)$ & $19.2(0.9-154.8)$ & $23.8(5.1-272.6)$ & $17.9(1.9-213.8)$ & 0.74 \\
\hline Total proteins $(\mathrm{mg} / \mathrm{L})$ & $1740(870-4120)$ & $1800(1050-3630)$ & $1830(870-4120)$ & $1640(991-2330)$ & 0.26 \\
\hline Creatinine (mg/dL) & $1.89(0.71-7.3)$ & $1.83(0.71-3.16)$ & $1.94(1.19-2.97)$ & $1.92(1.33-7.3)$ & 0.76 \\
\hline Cystatin C $(\mu \mathrm{g} / \mathrm{L})$ & $882(64-2678)$ & $779(64-2678)$ & $889(441-2110)$ & $1025(244-2461)$ & 0.22 \\
\hline $\mathrm{RBP}(\mu \mathrm{g} / \mathrm{L})$ & $2000(509-24,350)$ & $1980(618-10,500)$ & $1900(509-13,250)$ & $2100(640-24,350)$ & 0.85 \\
\hline$\beta_{2} \mathrm{~m}(\mu \mathrm{g} / \mathrm{L})$ & $2000(180-4320)$ & $2010(180-4320)$ & $2070(1120-4090)$ & $1950(430-3530)$ & 0.93 \\
\hline Albumin (mg/L) & $1380(28-3960)$ & $1260(28-3960)$ & $1470(959-2950)$ & $1450(811-2870)$ & 0.59 \\
\hline Transferrin (mg/L) & $125(51-633)$ & $124(51-508)$ & $125(58-633)$ & $126(55-279)$ & 0.99 \\
\hline Cortisol (nmol/L) & $119(52-206)$ & $120(56-206)$ & $120(91-153)$ & $118(52-189)$ & 0.97 \\
\hline
\end{tabular}

Values are given as geometric mean with range.

* Differences between smoking categories were assessed by ANOVA followed by Dunnett's multiple comparison test.
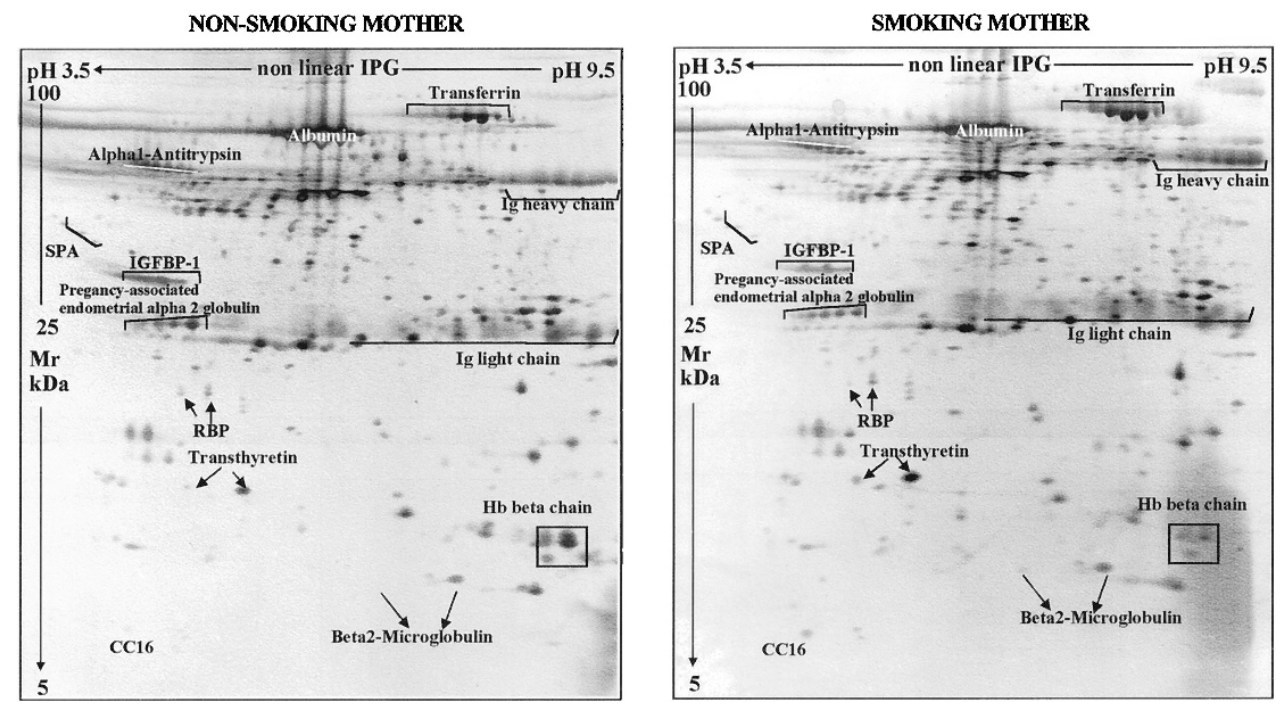

Figure 1. Two-dimensional protein map of human AF obtained at term from a nonsmoking (left panel) and a smoking mother (right panel). Identified proteins are reported. The gel image was processed with the PDQuest computer system. IGFBP-1, IGF binding protein.

Table 3. Relationship between the biochemical parameters in amniotic fluid

\begin{tabular}{|c|c|c|c|c|c|c|c|c|c|}
\hline & $\begin{array}{c}\mathrm{CC} 16 \\
p \text {-value } \\
\left(\mathrm{r}_{\mathrm{s}}\right) \\
\end{array}$ & $\begin{array}{c}\text { SP-A } \\
p \text {-value } \\
\left(\mathrm{r}_{\mathrm{s}}\right) \\
\end{array}$ & $\begin{array}{c}\text { Creatinine } \\
p \text {-value } \\
\left(\mathrm{r}_{\mathrm{s}}\right)\end{array}$ & $\begin{array}{c}\text { T. Protein } \\
p \text {-value } \\
\left(\mathrm{r}_{\mathrm{s}}\right)\end{array}$ & $\begin{array}{c}\text { Cystatin-C } \\
p \text {-value } \\
\left(\mathrm{r}_{\mathrm{s}}\right) \\
\end{array}$ & $\begin{array}{c}\mathrm{RBP} \\
p \text {-value } \\
\left(\mathrm{r}_{\mathrm{s}}\right) \\
\end{array}$ & $\begin{array}{c}\beta_{2}-\mathrm{m} \\
p \text {-value } \\
\left(\mathrm{r}_{\mathrm{s}}\right)\end{array}$ & $\begin{array}{c}\text { Albumin } \\
p \text {-value } \\
\left(\mathrm{r}_{\mathrm{s}}\right)\end{array}$ & $\begin{array}{c}\text { Transferrin } \\
p \text {-value } \\
\left(\mathrm{r}_{\mathrm{s}}\right)\end{array}$ \\
\hline $\mathrm{CC} 16$ & - & & NS & NS & & & & & \\
\hline Cystatin C & $0.0001(0.47)$ & NS & NS & NS & & & & & \\
\hline $\mathrm{RBP}$ & $0.0001(0.53)$ & NS & NS & NS & $0.0001(0.58)$ & & & & \\
\hline$\beta_{2}-\mathrm{m}$ & $0.0023(0.34)$ & NS & NS & NS & $0.0001(0.55)$ & $0.0001(0.48)$ & & & \\
\hline Gestational age & NS & $0.0093(0.31)$ & NS & NS & NS & NS & NS & NS & NS \\
\hline Cortisol & NS & $0.02(0.26)$ & NS & NS & $0.001(0.38)$ & $0.04(0.25)$ & NS & NS & NS \\
\hline
\end{tabular}

CC16, amniotic $16 \mathrm{kDa}$ Clara cell secretory protein; SP-A, amniotic surfactant-associated protein A; Creatinine, amniotic creatinine; T. Proteins, amniotic total proteins; Cystatin C, amniotic cystatin C; RBP, amniotic retinol binding protein; $\beta_{2}-\mathrm{m}$, amniotic $\beta_{2}$-microglobulin; Albumin, amniotic albumin; Transferrin, amniotic transferrin; Cortisol, amniotic free cortisol $(p>0.05)$.

well as exposure to other outdoor or indoor pollutants never emerged as a significant determinant for CC16 and SP-A level and for other nonpulmonary proteins present in AF (Table 4).

\section{DISCUSSION}

To test the hypothesis that tobacco smoking during pregnancy affects fetal pulmonary epithelium in utero, $\mathrm{CC} 16$ and
SP-A, two major secretory proteins of the bronchial and alveolar epithelium, were measured in AF obtained at term from smoking and nonsmoking women. Although the fetal lung is the main if not exclusive source of these proteins in AF, there are, however, a number of extrapulmonary factors that may affect the concentrations of proteins in AF, including gestational age and kidney maturity (11). To determine the influence 


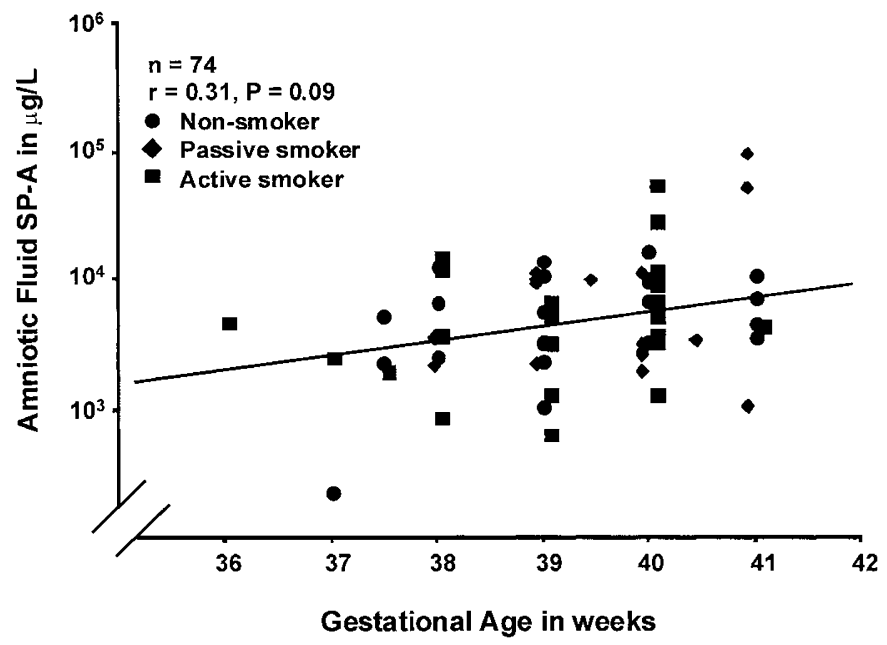

Figure 2. SP-A levels in $\mathrm{AF}$ at different gestational ages.

Table 4. Determinants of $C C 16$ and $S P-A$ in amniotic fluid

\begin{tabular}{clccl}
\hline $\begin{array}{c}\text { Dependent } \\
\text { variables }\end{array}$ & Independent variables* & Partial $r^{2}$ & Slope & $p$-Value* \\
\hline CC16 & LMWP & & & \\
& Model 1: RBP & 0.25 & 0.47 & 0.0001 \\
& Model 2: Cystatine C & 0.22 & 0.55 & 0.0008 \\
& Model 3: $\beta_{2}$-m & 0.14 & 0.53 & 0.001 \\
& HMWP & & & \\
& Model 1: Albumin & 0.064 & 0.48 & 0.03 \\
$\quad$ Model 2: Transferrin & 0.072 & 0.38 & 0.01 \\
$\quad$ SP-A & Gestational age & 0.14 & 14.58 & 0.006 \\
\hline
\end{tabular}

* Tested independent variables were exposure to tobacco smoke, exposure to outdoor or indoor sources of pollutants, LMWP in AF (testing separately in different regression models RBP, cystatin $C$, and $\beta_{2}-\mathrm{m}$ ), HMWP (testing separately in different regression models albumin or transferrin), sex, gestational age at birth, and creatinine in $\mathrm{AF}$.

of these factors, we have determined in this study the concentrations in AF of several LMWP and HMWP originating from the lung or extrapulmonary organs.

A first observation is that significant correlations emerged between $\mathrm{CC} 16$ and nonpulmonary proteins. The strongest correlations were found with LMWP, which are assumed to derive largely from fetal urinary excretion and to reflect the function and maturation of the fetal kidney tubules (27-30). By contrast, CC16 in AF was much less correlated with HMWP, which are largely retained by the fetal glomerular filter (26). Altogether, these observations suggest that in the fetus, as in adults, there is a leakage of $\mathrm{CC} 16$ from the lung into the fetal circulation from where it is cleared by the fetal kidney. On the basis of the partial regression coefficients, the relative contribution of the two sources of CC16 in AF, namely the washing by the AF and the intravascular leakage/renal filtration route, were estimated to be $80 \%$ and $20 \%$ respectively. Thus, changes of CC16 in $\mathrm{AF}$ are largely related to the secretory activity of the fetal lung. By contrast with CC16, SP-A did not correlate with either LMWP or HMWP in AF, suggesting that, as in adults, this protein is not filtered by the glomeruli and enters the AF only as a result of its secretion in AF.

Our main finding is that the levels of CC16 in AF were not significantly different between smokers and nonsmokers. This is in contrast with the well-documented effect of tobacco smoking on the lungs of smokers who exhibit a marked reduction of Clara cell number and decreased levels of CC16 in sputum, bronchoalveolar lavage fluid, and serum $(18,19,44)$. This sensitivity of Clara cells to tobacco smoke injury might result from to the cytochrome-P-450-mediated metabolic activation, particularly active in Clara cells, of chemicals present in tobacco smoke $(19,45)$. A direct irritating effect of tobacco smoking on airway epithelial cells has, however, so far not been formally ruled out. The levels of SP-A were also not significantly different in $\mathrm{AF}$ of smokers when compared with nonsmokers. It is, however, important to point out that, by contrast with $\mathrm{CC} 16$, conflicting results have been reported with regard to the effect of tobacco smoking on levels of SP-A in bronchoalveolar lavage fluid of adults (46-48).

These results were confirmed by two-dimensional gel electrophoresis of AF samples from pregnant women. To our knowledge, this is the first reported 2-D protein map of AF proteins at term. This map is very similar to that established at wk 17 by Liberatori and colleagues, with the exception of the absence of $\mathrm{CC} 16$ and SP-A, which are not detectable in AF at this time of gestation (49). For the three smoking categories, the map comprises approximately the same number of spots, which suggests that the protein pattern in AF is not qualitatively affected by maternal tobacco smoking. Quantitative comparison did not reveal significant differences for pulmonary (CC16 and SP-A) and nonpulmonary proteins (RBP, $\beta_{2}-\mathrm{m}$, albumin, and transferrin) identified on the electrophoretograms of smoking and nonsmoking mothers.

It is unlikely that the conclusions of our study have been biased by misclassification of exposure to tobacco smoke and other pollutants. We indeed considered maternal self-report of tobacco smoking as the most reliable parameter to evaluate newborn exposure inasmuch as hyper-reporting of tobacco smoking appears very unlikely. Although cotinine in maternal urine or AF was used to identify passive or unreported smoking, this parameter showed low values in both fluids compared with other studies (23). The best explanation is that women markedly reduced or refrained from smoking $24-48 \mathrm{~h}$ before labor. In agreement with the literature, body weight of infants born to mothers who smoked during pregnancy was on average $300 \mathrm{~g}$ lower than nonexposed mothers and negatively correlated with the cumulative smoking during pregnancy. With respect to exposure to other sources of indoor or outdoor pollutants, no difference was found between the three smoking categories.

Several explanations might be provided to account for the absence of reduction of CC16 in AF among smoking women. First, Clara cell toxicants inhaled by the mother may not reach the human placental barrier, as would be the case for direct irritating substances. Second, if absorbed, these substances might occur in amounts too small to induce Clara cell damage. Third, these toxicants may not be bioactivated by Clara cells, which are probably not completely mature. Altogether, these findings suggest that nonciliated Clara cells and alveolar cells are not a direct target of injury by tobacco exposure in utero.

Our study further suggests that the degree of maturation and secretory function of the pulmonary epithelium at term are not altered by exposure in utero to tobacco smoke. The absence of 
change of CC16 and SP-A in AF of newborns of smokeexposed mothers markedly contrasts with the marked reduction of CC16 and SP-A in fetuses with pathologies associated with lung hypoplasia or immaturity. CC16 and SP-A levels have indeed been found to be severely decreased in AF of humans or animal fetuses with diaphragmatic hernia or born from diabetic mother $(12,16,17)$. Finally, our findings do not contradict previous studies, which have consistently shown an acceleration of lung maturation of smoke-exposed fetuses as estimated by the higher levels the lecithin/sphingomyelin ratio in AF obtained at about wk 34 (31). Increased production or secretion of cortisol induced by nicotine has been suggested to account for this effect of maternal smoking on fetal lung maturation (31). By contrast with this report, we found no difference in the cortisol content of amniotic fluid obtained at term from smoking and nonsmoking mothers. Although our study was not intended to evaluate the rate of maturation of the fetal lung in relation with tobacco smoke exposure, it clearly suggests that the degree of maturity at term is not significantly affected by maternal smoking.

Alterations of lung functions tests compatible with airway obstruction are well-established consequences of maternal smoking. These effects have been recently documented in premature infants born at a mean age of 33.4 wk to mothers who smoked during pregnancy, suggesting that they occur before birth and are not caused by postnatal environmental tobacco smoke exposure (4). The absence of changes of lung epithelium-specific proteins in $\mathrm{AF}$, however, suggests that these functional changes occur independently of alterations of the growth and the secretory function of the airway and alveolar epithelium. As already suggested by others, these deleterious functional changes might represent disturbances in the neural control of breathing rather than ultrastructural changes of the airways (50).

In conclusion, our study suggests that maternal smoking during pregnancy is not associated with alterations of the development and secretory functions of the epithelium of the distal airways and the alveoli at term. These observations should contribute to a better understanding of the effects of maternal tobacco smoking on the fetal lung.

Acknowledgments. The authors are grateful for the skilled assistance of Françoise Martin (St.-Vincent Clinics, Rocourt) for her contribution to the data collection, and Xavier Dumont and Johan Casters (Unit of Industrial Toxicology) for performing analyses on amniotic fluids.

\section{REFERENCES}

1. Gidding SS, Schydlower M 1994 Active and passive tobacco exposure: a serious pediatric health problem. Pediatrics 94:750-751

2. Stick SM, Burton PR, Gurrin L, Sly PD, LeSouef PN 1996 Effects of maternal smoking during pregnancy and a family history of asthma on respiratory function in newborn infants. Lancet 348:1060-1064

3. Byrd RS, Howard CR 1995 Children's passive and prenatal exposure to cigarette smoke. Pediatr Ann 24:640-642, 644-645

4. Hoo AF, Henschen M, Dezateux C, Costeloe K, Stocks J 1998 Respiratory function among preterm infants whose mothers smoked during pregnancy. Am J Respir Crit Care Med 158:700-705

5. Hanrahan JP, Tager IB, Segal MR, Tosteson TD, Castile RG, Van Vunakis H, Weiss ST, Speizer FE 1992 The effect of maternal smoking during pregnancy on early infant lung function. Am Rev Respir Dis 145:1129-1135
6. Tager IB, Hanrahan JP, Tosteson TD, Castile RG, Brown RW, Weiss ST, Speizer FE 1993 Lung function, pre- and post-natal smoke exposure, and wheezing in the first year of life. Am Rev Respir Dis 147:811-817

7. Lodrup Carlsen KC, Jaakkola JJ, Nafstad P, Carlsen KH 1997 In utero exposure to cigarette smoking influences lung function at birth. Eur Respir J 10:1774-1779

8. Antrup H, Vestergaard AB, Okkels H 1995 Transplacental transfer of environmental genotoxins: polycyclic aromatic hydrocarbon-albumin in non-smoking women, and the effect of maternal GSTM1 genotype. Carcinogenesis 16:1305-1309

9. Lahdetie J, Engstrom K, Husgafvel-Pursiainen K, Nylund L, Vainio H, Sorsa M 1993 Maternal smoking induces cotinine levels and genotoxicity in second trimester amniotic fluid. Mutat Res 300:37-43

10. Dinsdale D 1995 Lung injury: cell-specific bioactivation/deactivation of circulating pneumotoxins. Int J Exp Path 76:393-401

11. Hermans C, Bernard A 1999 Lung epithelium-specific proteins. Characteristics and potential applications as markers. Am J Respir Crit Care Med 159:646-678

12. Bernard A, Thielemans N, Lauwerys R, Langhendries JP, Van Lierde M, Freund MM 1994 Clara cell protein in human amniotic fluid: a potential marker of fetal lung growth. Pediatr Res 36:771-775

13. Miyamura K, Malhotra R, Hoppe HJ, Reid KB, Phizackerley PJ, Macpherson P, Lopez Bernal A 1994 Surfactant proteins A SP-A and D SP-D: levels in human amniotic fluid and localization in the fetal membranes. Biochim Biophys Acta 1210:303-307

14. King RJ, Ruch J, Gikas EG, Platzker AC, Creasy RK 1975 Appearance of paoproteins of pulmonary surfactant in human amniotic fluid. J Appl Physiol 39:735-741

15. Pryhuber GS, Hull WM, Fink I, McMahan MJ, Whitsett JA 1991 Ontogeny of surfactant proteins A and B in human amniotic fluid as indices of fetal lung maturity. Pediatr Res 30:597-605

16. Mysore MR, Margraf LR, Jaramillo MA, Breed DR, Chau VL, Arevalo M, Moya FR 1998 Surfactant protein A is decreased in a rat model of congenital diaphragmatic hernia. Am J Respir Crit Care Med 157:654-657

17. Snyder JM, Kwun JE, O'Brien JA, Rosenfeld CR, Odom MJ 1988 The concentration of the $35-\mathrm{kDa}$ surfactant apoprotein in amniotic fluid from normal and diabetic pregnancies. Pediatr Res 24:728-734

18. Shijubo N, Itoh Y, Yamaguchi T, Shibuya Y, Morita Y, Hirasawa M, Okutani R, Kawai T, Abe S 1997 Serum and BAL Clara cell $10 \mathrm{kDa}$ protein CC10 levels and CC10-positive bronchiolar cells are decreased in smokers. Eur Respir J 10:11081114

19. Bernard AM, Roels HA, Buchet JP, Lauwerys RR 1994 Serum Clara cell protein: an indicator of bronchial cell dysfunction caused by tobacco smoking. Environ Res 66:96-104

20. Singh G, Katyal SL 1997 Clara cells and Clara cell 10 kD protein CC10. Am J Respir Cell Mol Biol 17:141-143

21. Wright JR 1997 Immunomodulatory functions of surfactant. Physiol Rev 77:931-962

22. Haufroid V, Lison D 1998 Urinary cotinine as a tobacco-smoke exposure index: a minireview. Int Arch Occup Environ Health 71:162-168

23. Jordanov JS 1990 Cotinine concentrations in amniotic fluid and urine of smoking, passive smoking and non-smoking pregnant women at term and in the urine of their neonates on 1st day of life. Eur J Pediatr 149:734-737

24. Rask L, Anundi H, Bohme J, Eriksson U, Fredriksson A, Nilsson SF, Ronne H, Vahlquist A, Peterson PA 1980 The retinol-binding protein. Scand J Clin Lab Invest Suppl 154:45-61

25. Grubb A 1992 Diagnostic value of analysis of cystatin C and protein $\mathrm{HC}$ in biological fluids. Clin Nephrol 38(Suppl 1):S20-S27

26. Bernard A, Lauwerys RR 1991 Proteinuria: changes and mechanisms in toxic nephropathies. Crit Rev Toxicol 21:373-405

27. Padovani EM, Fanos V, Mussap M, Plebani M, Burlina A 1994 Tubular proteins and enzyme content in the amniotic fluid. Eur J Obstet Gynecol Reprod Biol 55:129-133

28. Mussap M, Fanos V, Piccoli A, Zaninotto M, Padovani EM, Plebani M 1996 Low molecular mass proteins and urinary enzymes in amniotic fluid of healthy pregnant women at progressive stages of gestation. Clin Biochem 29:51-56

29. Burghard R, Pallacks R, Gordjani N, Leititis JU, Hackeloer BJ, Brandis M 1987 Microproteins in amniotic fluid as an index of changes in fetal renal function during development. Pediatr Nephrol 1:574-580

30. Burghard R, Gordjani N, Leititis J, Bald R 1987 Protein analysis in amniotic fluid and fetal urine for the assessment of fetal renal function and dysfunction. Fetal Ther 2:188-196

31. Lieberman E, Torday J, Barbieri R, Cohen A, Van Vunakis H, Weiss ST 1992 Association of intrauterine cigarette smoke exposure with indices of fetal lung maturation. Obstet Gynecol 79:564-570

32. Hermans C, Osman Aly, Nyberg BI, Peterson C, Bernard A 1998 Determinants of Clara cell protein $\mathrm{CC} 16$ concentration in serum: a reassessment with two different immunoassays. Clin Chim Acta 272:101-110

33. Bernard A, Marchandise FX, Depelchin S, Lauwerys R, Sibille Y 1992 Clara cell protein in serum and bronchoalveolar lavage. Eur Respir J 5:1231-1238

34. Doyle IR, Jones ME, Barr HA, Orgeig S, Crockett AJ, McDonald CF, Nicholas TE 1994 Composition of human pulmonary surfactant varies with exercise and level of fitness. Am J Respir Crit Care Med 149:1619-1627

35. Bernard AM, Lauwerys RR 1983 Continuous-flow system for automation of latex immunoassay by particle counting. Clin Chem 29:1007-1011

36. Bernard AM, Lauwerys RR 1982 Comparison of turbidimetry with particle counting for the determination of human beta 2-microglobulin by latex immunoassay LIA. Clin Chim Acta 119:335-339

37. Murphy BE 1978 Conjugated glucocorticoids in amniotic fluid and fetal lung maturation. J Clin Endocrinol Metab 47:212-215 
38. Rop PP, Grimaldi F, Oddoze C, Viala A 1993 Determination of nicotine and its main metabolites in urine by high-performance liquid chromatography. J Chromatogr 612:302-309

39. Wattiez R, Hermans C, Cruyt C, Bernard A, Falmagne P 2000 Human bronchoalveolar lavage fluid protein two-dimensional database: study of interstitial lung diseases. Electrophoresis 21:2703-2712

40. Gorg A, Postel W, Gunther S 1988 The current state of two-dimensional electrophoresis with immobilized $\mathrm{pH}$ gradients. Electrophoresis 9:531-546

41. Rabilloud T 1996 Solubilization of proteins for electrophoretic analyses. Electrophoresis 17:813-829

42. Bini L, Magi B, Marzocchi B, Cellesi C, Berti B, Raggiaschi R, Rossolini A, Pallini V 1996 Two-dimensional electrophoretic patterns of acute-phase human serum proteins in the course of bacterial and viral diseases. Electrophoresis 17:612-616

43. Wattiez R, Hermans C, Bernard A, Lesur O, Falmagne P 1999 Human bronchoalveolar lavage fluid: two-dimensional gel electrophoresis, amino acid microsequencing and identification of major proteins. Electrophoresis 20:1634-1645

44. Bernard AM, Gonzalez Lorenzo JM, Siles E, Trujillano G, Lauwerys R 1994 Early decrease of serum Clara cell protein in silica-exposed workers. Eur Respir J 7:1932-1937
45. Boyd MR 1977 Evidence for the Clara cell as a site of cytochrome P450-dependent mixed-function oxidase activity in lung. Nature 269:713-715

46. Honda Y, Takahashi H, Kuroki Y, Akino T, Abe S 1996 Decreased contents of surfactant proteins A and D in BAL fluids of healthy smokers. Chest 109:10061009

47. Hamm H, Luhrs J, Guzman R, Costabel U, Fabel H, Bartsch W 1994 Elevated surfactant protein A in bronchoalveolar lavage fluids from sarcoidosis and hypersensitivity pneumonitis patients. Chest $106: 1766-1770$

48. Lesur O, Bernard AM, Begin RO 1996 Clara cell protein CC-16 and surfactantassociated protein A SP-A in asbestos-exposed workers. Chest 109:467-474

49. Liberatori S, Bini L, De Felice C, Magi B, Marzocchi B, Raggiaschi R, Frutiger S, Sanchez JC, Wilkins MR, Hughes G, Hochstrasser DF, Bracci R, Pallini V 1997 A two-dimensional protein map of human amniotic fluid at 17 weeks' gestation. Electrophoresis 18:2816-2822

50. Milerad JH, Larsson H, Lin J, Sundel HW 1995 Nicotine attenuates the ventilatory response to hypoxia in the developing lamb. Pediatr Res 37:652660 